\title{
PEMILIHAN LOKASI USAHA DAN PENGARUHNYA TERHADAP KEBERHASILAN USAHA JASA BERSKALA MIKRO DAN KECIL
}

\author{
SANDRA FITRIYANI \\ TRISNA MURNI \\ SRI WARSONO \\ Program Studi Manajemen, Fakultas Ekonomi dan Bisnis \\ Universitas Bengkulu
}

\begin{abstract}
The success of the business of entrepreneurs who are in the area behind Unib is very influenced by the factor of location or place of business. Place business which is getting closer to UNIB will be more and more consumers. A strategic place of business will have a profitable impact for businessmen, because the place of business is easily known and easily accessible by consumers, especially students. Research on the Selection of Business Locations and their Influence on Micro and Small Scale Business Success, aims to know the contribution in obtaining profit, and to analyze the influence of business environment factor and location cost on business success. The indicators used in the measurement of this study are competitor, consumer, rent, tax, profit rate and others. In this research use quantitative descriptive analysis method by using multiple regression statiistic tool. The result of the research shows that location selection based on business environment factor and location cost factor have influence to business success. The better the business environment conditions in that location will be easier to achieve success, and vice versa. The size of the costs incurred to obtain the business location, will determine the strategic place of business. A strategic place of business, will accelerate business success. This is supported by the perception of respondents that the success of the business is determined by: customer arrival rate / day, net profit growth, $B E P$ time, rate of return, profit which all of the average value agree.
\end{abstract}

Keyword: Business Environment, Location Cost, Business Success. 


\section{PENDAHULUAN}

Menjalankan usaha atau bisnis terdapat banyak faktor yang harus di perhatikan oleh pengusaha demi keberhasilan usahanya. Lokasi perusahaan merupakan kunci bagi efisiensi dan efektifitas keberlangsungan perusahaan jangka panjang" (Haming \& Nurnajamuddin, 2007 : 47). Untuk bisa mempertahankan hidup pengusaha harus bekerja keras dan mampu berkompetisi dengan para kompetitor. Dalam situasi persaingan, faktor lokasi dapat menjadi faktor-faktor yang kritis dan membuatnya menjadi sangat penting (Handoko, 2000:65).

Keputusan pemilihan lokasi strategis yang digunakan biasanya adalah strategi untuk meminimalkan biaya, sedang untuk bisnis eceran dan jasa profesional, strategi yang digunakan terfokus pada memaksimalkan pendapatan(Heizer \& Render, 2009:486).Usahawan sering membuat kesalahan dalam pemilihan lokasi dan tempat fasilitas-fasilitas produksinya. Misal,dapat lokasi, tenaga kerja sulit diperoleh,lokasi harga murah, tetapi kondisi tanah jelek, sehingga perusahaan harus mengeluarkan biaya ekstra dalam membangun fondasinya. Kesalahan-kesalahan tersebut dapat mengakibatkan perusahaan beroperasi dengan tidak efisien dan tidak efektif.

Faktor yangperludipertimbangkan dalam pemilihan lokasi, meskipun ada beberapa faktor yang berpengaruh, namun faktor kedekatan dengan pasar (konsumen), lebih diutamakan untuk jenis usaha jasa. Lokasi ini bisa dilihat: 1) Lingkungan bisnis, yaitu mengenai kedekatan lokasi usaha dengan usaha lain/pesaing, kedekatan dengan konsumen, , kedekatan dengan supplier, dan kedekatan penyedia peralatan/perlengkapan produksi. 2) Biaya lokasiyaitu mengenai harga sewa bangunan, ada tidaknya biaya renovasi, tingkat suku bunga, biaya tenaga kerja, dan besarnya pajak. Kedua faktor inilah yang harus dipertimbangkan dalam pemelihan lokasi karena menentukan baiya yang harus dikeluarkan dan keuntungan yang akan diperoleh serta keberhasilan yang akan dicapai.

Beberapa faktor yang dapat menyebabkan kegiatan usahanya mengalami pasang surut bahkan tutup, salah satu faktornya adalah kesalahan dalam memilih lokasi/tempat usaha. Fu'ad (2015) dalam penelitianya menyimpulkan bahwa kesuksesan suatu usaha jasa bergantung pada pemilihan lokasi yang tepat. Kawasan disekitar UNIB menjadi lokasi usaha strategis, dan membuka peluang bagi para pengusaha untuk membuka usaha.Saat ini banyak usaha kecil yang bergerak disektor jasa seperti , foto copy, cost-costsan, salon, warnet, cuci motor, Londry, dan lain-lain. Sampai saat ini dikawasan UNIB belakang jumlah pengusaha ada 85 usaha yang bergerak dalam bidang jasa (survey. 10-7-2017). Hal ini menunjukkan adanya gejala persaingan antara pengusaha satu dengan yang lainya. 


\section{TINJAUAN PUSTAKA}

\section{Lokasi}

Lokasi diartikan letak kedudukan fisik sebuah usaha di dalam daerah tertentu (Levy \&Weitz, 2007). Lokasi adalah tempat untuk setiap bisnis dan merupakan suatu keputusan penting, karena keputusan yang salah dapat mengakibatkan kegagalan sebelum bisnis dimulai (Rbayulia, 2013). Memilih lokasi usaha harus benar-benar dipertimbangkan dengan hati-hati karena kemudahan untuk menjangkau tempat usaha sangat mempengaruhi kedatangan konsumen.

Teori Lokasi Losch dan Weber, dari Losch yang melihat persoalan dari sisi permintaan (pasar), dan Weber yang melihat persoalan dari sisi penawaran (produksi). Losch mengatakan bahwa lokasi penjual sangat berpengaruh terhadap jumlah konsumen yang dapat digarapnya. Makin jauh dari tempat penjual, konsumen makin enggan membeli karena biaya transportasi untuk mendatangi tempat penjual semakin mahal. Losch cenderung menyarankan agar lokasi produksi berada di pasar atau di dekat pasar.

Lokasi usaha adalah pemacu biaya yang begitu signifikan, lokasi usaha memiliki kekuatan untuk membuat atau menghancurkan strategi bisnis sebuah usaha. Disaat pemilik usaha memutuskan lokasi usahanya dan beroperasi di satu lokasi tertentu, banyak biaya akan menjadi tetap dan sulit untuk dikurangi. Pemilihan lokasi usaha mempertimbangkan antara strategi pemasaran jasa dan preferensi pemilik.

Pemilihan lokasi usaha merupakan salah satu keputusan bisnis yang harus dibuat secara hati-hati. Penelitian-penelitian terdahulu menemukan bahwa lokasi usaha berpengaruh terhadap kesuksesan atau keberhasilan usaha (Wahyudi \& Heriyanto, 2014). Namun, penelitian-penelitian tersebut masih didominasi oleh pemilihan lokasi di sektor manufaktur, industri teknologi tinggi, dan perusahaan besar, dimana pemilihan lokasi usaha-usaha tersebut didorong oleh pertimbangan besarnya biaya transportasi bahan produksi.

Ketepatan pemilihan lokasi merupakan salah satu faktor yang perlu dipertimbangkan oleh seorang pengusaha sebelum membuka usahanya. Pemilihan lokasi yang tepat seringkali menentukan keberhasilan suatu usaha. Kesalahan pemilihan lokasi dapat menghambat keberhasilan usaha. Menurut Kotler (2008:51) "Salah satu kunci menuju keberhasilan/sukses adalah lokasi, lokasi dimulai dengan memilih komunitas". Keputusan ini sangat bergantung pada potensi pertumbuhan ekonomis dan stabilitas, persaingan, iklim bisnis, dan sebagainya.

Menurut Haming\&Nurnajamuddin(2007:149-153) pertimbangan yang perlu mendapatkan perhatian manajemen adalah sebagai berikut: 
1. Perencanaan jangka panjang perusahaan, maka manajemen perlu mempertimbangkan kemungkinan perluasan area jika dimasa datang perusahaan akan melakukan ekspansi atau peningkatan kapasitas.

2. Kedekatan dengan sumber bahan, jika perusahaan memerlukan bahan baku dalam volume yang besar,sulit diangkut,dll maka perusahaan memilih lokasi dekat dengan sumber bahan dan apabila perusahaan membutuhkan bahan baku dalam volume besar,tapi mudah diangkut, dll maka perusahaan seperti ini memilih lokasi yang dekat dengan pasar.

3. Kedekatan dengan pasar, biasanya perusahaan cenderung memilih lokasi yang dekat dengan pasar.

4. Iklim bisnis, suatu iklim bisnis yang baikdapat meliputi hadirnya bisnis yang serupa ukurannya.

5. Biaya, tujuan kriteria ini adalah mendorong usaha industri ataupun jasa untuk memilih lokasi yang akan meminimumkan biaya.

6. Kedekatan infrastruktur, perusahaan industri ataupun jasa sangat memerlukan dukungan berbagai macam prasarana, seperti jalan raya, rel kereta api, hubungan udara, pasokan listrik, air, sarana telekomunikasi, dan energi.

7. Ketersediaan tenaga kerja dan kualitas tenaga kerja, di lokasi harus tersedia pasokan tenaga kerja yang diperlukan oleh usahawan pabrik atau jasa, baik dari sisi jumlahnya ataupun dari sisi kualitasnya.

8. Ketersediaan pembekal, pembekal adalah mitra usahawan dalam mengelolah bisnisnya.

9. Kebijakan pemerintah dan risiko politik, beberapa negara memberikan pembatasan dalam penempatan usaha industri asing dinegaranya.

10. Zona perdagangan bebas, beberapa negara menunjuk wilayah tertentu dinegaranya sebagai kawasan perdagangan bebas dengan berbagai insentif pajak di dalamnya.

11. Blok perdagangan, dewasa ini dijumpai pula kalaborasi beberapa negara di kawasan tertentu untuk membentuk blok perdagangan.

12. Keamanan, faktor keamanan merupakan faktor yang sangat dipertimbangkan oleh pengusaha dalam pemilihan lokasi.

13. Aturan lingkungan, semakin sadar masyarakat akan kelestarian lingkungan, maka isu lingkungan menjadi penting dalam pemilihan lokasi.

14. Penerimaan masyarakat lokal, merupakan suatu hal yang penting untuk diperhatikan.

15. Keunggulan bersaing, suatu keputusan penting untuk perusahaan multinasional ialah pemilihan atas negara yang menjadi tempat kedudukan dari masing-masing bisnis yang berbeda.

Sedangkan menurut Tjiptono (2007) pemilihan tempat atau lokasi usaha jasa memerlukan pertimbangan yang cermat terhadap beberapa faktor berikut :

1.Akses, misalnya lokasi yang mudah dilalui atau mudah dijangkau sarana transportasi umum.

2.Visibilitas, misalnya lokasi yang dapat dilihat dengan jelas dari tepi jalan.

3.Lalu lintas ( traffic ), dimana ada dua hal yang perlu dipertimbangkan, yaitu : 
- Banyaknya orang yang lalu lalang bisa memberikan besar terjadinya impulse buying .

- Kepadatan dan kemacetan lalu lintas bisa pula menjadi hambatan, misalnya terhadap pelayanan kepolisian, pemadam kebakaran, dan ambulans.

4.Tempat parkir yang luas dan aman.

5.Ekspansi, yaitu tersedia tempat yang cukup luas untuk perluasan usaha dikemudian hari.

6.Lingkungan bisnis, yaitu daerah sekitar yang mendukung jasa yang ditawarkan. Misalnya usaha fotokopi yang berdekatan dengan daerah kampus, sekolah, dan perkantoran.

7.Persaingan, yaitu lokasi pesaing. Misalnya dalam menentukan lokasi wartel, perlu dipertimbangkan apakah di jalan atau daerah yang sama banyak pula terdapat wartel lainnya.

8.Peraturan pemerintah, misalnya ketentuan yang melarang tempat reparasi (bengkel) kendaraan bermotor berdekatan dengan pemukiman penduduk.

Langkah dalam menentukan lokasi yang baik bagi usaha jasa adalah mengidentifikasi pasar yang paling potensial yang dapat ditemukan, karena lokasi usaha seringkali menentukan keberhasilan suatu usaha jasa (Fu'ad, 2015). Berikut adalah diantara faktor-faktor yang dapat mempengaruhi pemilihan lokasi suatu usaha.

1.Lingkungan bisnis, merupakan lingkungan yang dihadapi organisasi dan harusdipertimbangkan dalam pengambilan keputusan bisnis(perusahaan).Menurut Jatmiko (2004:30) lingkungan bisnis adalah suatu kekuatan, suatu kondisi, suatu keadaan, suatu peristiwa yang saling berhubungan dimana organisasi/perusahaan mempunyai atau tidak mempunyai kemampuan untuk mengendalikannya. Aktivitaskeseharian organisasi mencakup interaksi dengan lingkungan kerja. Hal ini termasuk hubungannya denganpelanggan,supliers, dan serikat dagang.Oleh karena itu lingkungan bisnis menjadi faktor yang harus diperhatikan dalam memilih lokasi usaha karena mempengaruhi keberhasilan

2. Biaya lokasi, juga harus menjadi pertimbangan dalam memilih lokasi usaha. Menurut Supriyono $(2000 ; 16)$, Biaya adalah harga perolehan yang dikorbankan atau digunakan dalam rangka memperoleh penghasilan atau revenue yang akan dipakai sebagai pengurang penghasilan. Biaya lokasi adalah sejumlah uang atau kas yang dikorbankan untuk mendapatkan tempat usaha atau biaya-biaya lain yang berhubungan dengan lokasi usaha. Biaya yang harus dikeluarkan yang berhubungan dengan lokasi usaha harus menjadi pertimbangan pemilik dalam memilih lokasi usahanya, seperti biaya sewa, biaya renovasi, tingkat suku bunga, biaya tenaga kerja dan pajak harus diperhitungkan secara cermat karena apabilah terjadi kesalahan maka dapat menghambat pencapaian keberhasilan usaha (Fu'ud, 2015).

\section{Pemilihan Lokasi Usaha Jasa}

Beberapa penelitian sebelumnya mencoba meneliti pemilihan lokasi pada usaha jasa. Penelitian-penelitian tersebut mencoba meneliti faktor yang mempengaruhi pemilihan lokasi usaha jasa. Didalam bukunya 
Haming\&Nurnajamuddin (2007:148) bahwa pemilihan lokasi berada ditangan top management sebuah perusahaan, baik pada usaha pabrik maupun usaha jasa. Dalam pemilihan lokasi itu, manajemen puncak perlu memperhitungkan pertimbangan berikut:

a.Lokasi itu berkaitan dengan investasi jangka panjang yang sangat besar jumlahnya yang berhadapan dengan kondisi-kondisi yang penuh ketidakpastian.

b.Lokasi itu menentukan suatu kerangka pembatas atau kendala operasi yang permanen(mencakup undang-undang, tenaga kerja, masyarakat, dan lain-lain) dan kendala itu mahal dan sulit untuk diubah.

c. Lokasi mempunyai akibat yang signifikan dengan posisi yang kompetitif perusahaan, yaitu akan meminimumkan biaya produksi dan juga biaya pemasaran keluaran yang dihasilkan.

Menurut Chase dkk (2004) keputusan pemilihan lokasi usaha manufaktur dan usaha jasa dipengaruhi oleh berbagai macam kriteria pemilihan yang mendasarkan pada kepentingan kompetitif. Diantara kriteria pemilihan tersebut adalah jarak ke pelanggan, iklim bisnis, total biaya yang harus dikeluarkan, infrastruktur, kualitas tenaga kerja, suplier, lingkungan masyarakat, dan pengaruh pajak.

Penempatan lokasi usaha di tempat yang strategis juga mempengaruhi perkembangan dan eksistensi usaha kedepannya. Lokasi yang strategis dan sesuai untuk jual beli sangat penting dan utama bagi para pengusaha mikro. Jika salah dalam memilih lokasi dan penempatan, maka usaha akan menjadi sulit untuk berkembang dan kesulitan dalam mendapatkan pembeli/konsumen.. Hal ini sesuai dengan ungkapan Hidayat (2012), ketepatan pemilihan lokasi merupakan salah satu faktor yang perlu dipertimbangkan oleh seorang pengusaha.Pemilihan lokasi yang tepat sering kali menentukan tingkat penjualan suatu bisnis. Lokasi yang tepat merupakan modal bagi pengusaha untuk beraktivitas, sehingga mampu memperoleh dan meningkatkan keuntungan dan menjaga kelangsungan bisnis".

\section{Pengertian Usaha Mikro-Kecil}

Menurut UU No. 9/1995 tentang Usaha Kecil yang dimaksud dengan usaha kecil adalah kegiatan ekonomi rakyat yang berskala kecil dalam memenuhi kriteria kekayaan bersih atau hasil penjualan tahunan seperti kepemilikan sebagaimana diatur dalam undang-undang ini. Usaha kecil yang dimaksud di sini meliputi usaha kecil informal dan usaha kecil tradisional. Usaha kecil informal adalah berbagai usaha yang belum terdaftar, belum tercatat, dan belum berbadan hukum, antara lain petani penggarap, industri rumah tangga, pedagang asongan, pedagang keliling, pedagang kaki lima, dan pemulung. Sedangkan usaha kecil tradisional adalah usaha yang menggunakan alat produksi sederhana yang telah digunakan secara turun temurun, dan berkaitan dengan seni dan budaya (Anoraga, 2002:45).

Menurut Undang- Undang No.20 tahun 2008 tentang Usaha Mikro dan Kecil pengertian dan kriteria masing-masing adalah sebagai berikut: 
1.Usaha mikroadalah usaha produktif milik orang perorangan dan/atau badan usaha perorangan yang memenuhi kriteria sebagaimana diatur dalam UndangUndang

2.Usaha Kecilmenurut Biro Pusat Statistik (BPS) usaha mikro adalah usaha yang pekerjanya lebih kecil dari 4 orang, termasuk tenaga kerja yang tidak dibayar, dan usaha kecil adalah usaha yang pekerjanya sebanyak 5-19 orang.

\section{Keberhasilan Usaha}

Keberhasilan dalam usaha merupakan sesuatu hal yang utama dari sebuah perusahaan, dimana segala aktivitas ditujukan untuk mencapai suatu keberhasilan. Dalam pengertian umum, keberhasilan menunjukan suatu keadaan yang lebih baik atau unggul dari pada masa sebelumnya. Keberhasilan dijadikan tolak ukur dari segala upaya dan kerja keras dari suatu kegiatan. Pengukuran keberhasilan usaha dapat berdeda antara satu usaha dengan yang lain atau anatara satu pemilik dengan pemilik usaha yang lainnya. Namun, keberhasilan suatu usaha dapat dilihat dari data subjektif ataupun objektif atas berbagai aspek, misalnya berdasarkan tingkat kedatangan pelanggan, pertumbuhan laba bersih, dan waktu yang dibutuhkan untuk mencapai titik impas usaha atau Break Even Point (BEP) (Nuritha et al, 2013).

Dua pengukuran yang dapat dipakai untuk mengukur keberhasilan suatu usaha yaitu, kinerja financial dan non-financial. Pengukuran financial merupakan pengukuran tradisional yang biasa digunakan untuk mengukur kinerja suatu usaha, biasanya berhubungan dengan tingkat pengembalian usaha (return on investment). Sedangkan pengukuran non-financial dapat dilihat dari kualitas produk yang dihasilkan, tingkat persediaan, produktivitas, fleksibilitas, kecepatan pengiriman, dan pegawai. Selain pengukuran financial dan non-financial terdapat juga pengukuran subjektif dan objektif. Pengukuran subjektif dapat didefinisikan sebagai keberhasilan yang diharapkan/diterima oleh pemilik usaha, sedangkan pengukuran objektif salah satunya dapat dilihat dari persentase aktual dari pertumbuhan penjualan atau tingkat keuntungan yang dicapai.

\section{Hipotesis}

Hipotesis adalah hubungan yang diperkirakan secara logis di antara dua atau lebih variabel yang diungkapkan dalam bentuk pernyataan yang dapat di uji (Sekaran, 2009:135). Hipotesis juga disebut sebagai jawaban sementara terhadap masalah yang dibahas, yang kebenarannya masih harus diuji. Hipotesis merupakan rangkuman dari kesimpulan-kesimpulan teoritis yang diperoleh dari penelaahan kepustakaan.

H1 = Lingkungan bisnis berpengaruh terhadap keberhasilan usaha.

H2 = Biaya lokasi berpengaruh terhadap Keberhasilan usaha. 


\section{Kerangka Analisis}

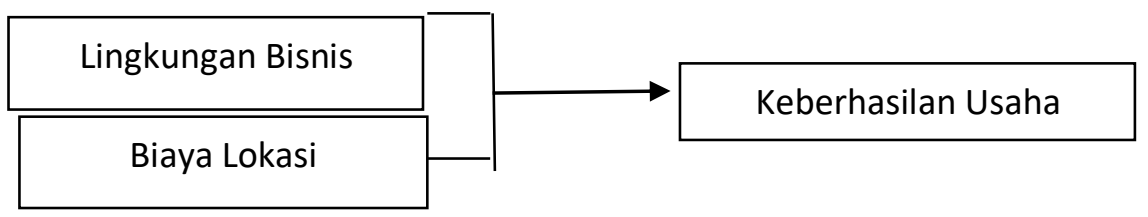

\section{METODE PENELITIAN}

Jenis Penelitian yang digunakan dalam penelitian ini adalah penelitian survey yaitu untuk mengetahui tentang keberadaan usaha mikro dan kecil yang berada dikawasan Unib belakang. Penelitian inibersifat deskriptif, penelitianyang dilakukan untuk mengetahui dan menjelaskan karakteristik variabel yang diteliti dalam suatu situsi (Sekaran, 2009:158). Tujuan dari penelitian ini adalah untuk menganalisis pengaruh pemilihan lokasi terhadap keberhasilan usaha jasa berskala mikro-kecil.

\section{Populasi dan Sampel}

Populasi merupakan wilayah generalisasi yang terdiri atas obyek yang mempunyai karakteristik tertentu dan mempunyai kesempatan yang sama untuk dipilih menjadi anggota sampel (Sekaran, 2005:77). Sampel adalah sebagian dari populasi. Sampel terdiri atas sejumlah anggota yang dipilih dari populasi (Sekaran, 2006:123).

Populasi penelitian ini adalah seluruh usaha jasa mikro-kecil di sepanjang jalan raya UNIB Belakang yang diwakili oleh pemilik usaha. Sampel dalam penelitian ini adalah keseluruhan usaha jasa mikro-kecil yaitu 85 responden dari usaha jasa meliputi: warnet, foto copy, Salon , laundry, jasa kost, penjait dan servis laptop.

\section{Metode Analisis}

Analisis merupakan sebuah proses berkelanjutan dalam penelitian, dengan analisis awal menginformasikan data yang kemudian dikumpulkan. Ketika peneliti sudah selesai dalam mengumpulkan data, maka langkah berikutnya ialah menganalisis data yang telah diperoleh dengan menggunakan Analisis regresi berganda

$\mathrm{Y}=\mathrm{b} 1 \mathrm{X} 1+\mathrm{b} 2 \mathrm{X} 2+\mathrm{e}$

$\mathrm{Y}=$ Keberhasilan usaha

b1=koefisien regresi dari variabel X1, lingkungan bisnis

b2 = koefisien regresi dari variabel X2, biaya lokasi

$\mathrm{X} 1=$ Lingkungan bisnis

$\mathrm{X} 2=$ Biaya lokasi

$\mathrm{e}=$ variabel penggangu 


\section{HASIL PENELITIAN DAN PEMBAHASAN}

\section{Analisis Regresi Berganda}

Analisis ini bertujuan untuk mengetahui seberapa besar pengaruh variabel bebas (lingkungan bisnis, dan biaya lokasi) terhadap variabel terikat yaitu keberhasilan usaha. Hasil persamaan model regresi berganda ditunjukkan pada tabel berikut ini :

\section{Tabel 4}

\section{Analisis Regresi Berganda}

\begin{tabular}{|c|c|c|c|c|c|}
\hline \multirow[b]{3}{*}{ Model } & & \multicolumn{2}{|c|}{ Coefficientsa } & \multirow[b]{3}{*}{$\mathrm{T}$} & \multirow[b]{3}{*}{ Sig. } \\
\hline & \multicolumn{2}{|c|}{$\begin{array}{l}\text { Unstandardized } \\
\text { Coefficients }\end{array}$} & $\begin{array}{c}\text { Standard } \\
\text { ized } \\
\text { Coefficie } \\
\text { nts }\end{array}$ & & \\
\hline & B & $\begin{array}{c}\text { Std. } \\
\text { Error }\end{array}$ & & & \\
\hline (Constant) & 2.763 & 1.352 & & $\begin{array}{r}2.04 \\
3\end{array}$ & .044 \\
\hline $\begin{array}{l}\text { Lingkungan } \\
\text { bisnis }\end{array}$ & .286 & .082 & .330 & $\begin{array}{r}3.48 \\
6\end{array}$ & .001 \\
\hline Biaya lokasi & .552 & .101 & .518 & $\begin{array}{r}5.47 \\
7\end{array}$ & .000 \\
\hline
\end{tabular}

a. Dependent Variable: Keberhasilan usaha

Sumber: Data Olahan (2017)

Berdasarkan Tabel 4 dengan menggunakan Standardized Coefficients, hasil analisis regresi dapat ditulis dalam persamaan sebagai berikut:

$\mathrm{Y}=0,330 \mathrm{X} 1+0,518 \mathrm{X} 2$

Persamaan diatas tampak masing-masing variabel independen memiliki koefisien regresi yang positif $(+)$, artinya kenaikan variabel independen akan diikuti oleh kenaikan variabel dependen. Variabel yang memiliki pengaruh paling besar adalah biaya lokasi dengan nilai beta 0,518 dan variabel lingkungan bisnis yakni sebesar 0,330.

\section{PEMBAHASAN}

Berdasarkan jawaban responden penelitian yang berjumlah 85 orang dapat diperoleh informasi mengenai pengaruh pemilihan lokasi terhadap keberhasilan usaha jasa berskala mikro-kecil khususnya yang berada di sepanjang Jalan Raya UNIB Belakang. Dapat diketahui bahwa seluruh variabel independen berpengaruh terhadap variabel dependen. Penjelasannya adalah sebagai berikut:

\section{Pengaruh Lingkungan Bisnis Terhadap Keberhasilan Usaha}

Berdasarkan teori yang dikemukakan oleh Tjiptono (2007)adanya pengaruh antara lingkungan bisnis dengan keberhasilan usaha, yaitu lingkungan bisnis merupakan variabel keberhasilan usaha yang penting yang harus dipertimbangkan secara cermat oleh pemilik usaha dalam memilih lokasi 
usahanya. Lingkungan bisnis mempengaruhi keberhasilan usaha karena aktivitas keseharian organisasi/usaha tidak bisa lepas dari lingkungan disekitarnya. Hal ini termasuk hubungannya dengan konsumen, bisnis lain, pesaing, dan supplier. Hubungan dengan kondisi lingkungan inilah yang dapat mempengaruhi keberhasilan usaha. Apabila hubungan pengusaha dengan kondisi lingkungan bagus maka akan cepat pula keberhasilan usaha dapat tercapai.

Penelitian terdahulu yang dilakukan oleh Indarti (2004) mengatakan bahwa lingkungan bisnis berpengaruh terhadap keberhasilan usaha. Sedangkan menurut penelitian Zuliarni \& Hidayat (2013) lingkungan bisnis merupakan faktor yang sangat penting bagi pemilik usaha dalam memilih lokasi usahanya. Hasil penelitian terdahulu ini sama dengan penelitian ini, yang mana variabel lingkungan bisnis berdasarkan penelitian yang telah dilakukan, diketahui bahwa lingkungan bisnis berpengaruh terhadap keberhasilan usaha. Hal dibuktikan dengan nilai signifikansi 0,001 lebih kecil dari 0,05 dan diperkuat oleh tanggapan responden yang menyatakan bahwa lingkungan bisnis penting dalam memilih lokasi usaha jasa dengan nilai indeks 0,786. dengan demikian variabel lingkungan bisnis (X1) berpengaruh terhadap keberhasilan usaha (Y). Hal ini menunjukkan bahwa semakin bagus kondisi lingkungan bisnis disekitarnya, maka semakin cepat keberhasilan usaha dapat tercapai.

\section{Pengaruh Biaya Lokasi Terhadap Keberhasilan Usaha}

Menurut teori yang dikemukakan oleh Handoko (2000) adanya pengaruh antara biaya lokasi dengan keberhasilan usaha, yaitu biaya lokasi merupakan variabel keberhasilan usaha yang sangat penting yang harus dipertimbangkan oleh pemilik usaha dalam memilih lokasi usahanya. Biaya lokasi mempengaruhi keberhasilan usaha karena apabilah biaya yang dikeluarkan dalam memperoleh lokasi usaha tidak sebanding dengan lokasi yang strategis, maka akan menghambat pencapaian keberhasilan usaha. Menurut Haming\&Nurnajamuddin(2007:149-153) biaya tujuannya adalah untuk mendorong usaha industri ataupun jasa untuk memilih lokasi yang akan meminimumkan biaya. Suatu usaha jasa memfokuskan pada maksimalisasi pendapatan, tentunya akan memilih lokasi yang dekat dengan konsumen atau lokasi usaha yang strategis. Lokasi usaha yang strategis akan dengan mudah terlihatolehkonsumen dan mudah dijangkau, sehingga akan banyak konsumen yang datang ke tempat usaha dan keberhasilan usaha cepat tercapai.

Penelitian terdahulu yang dilakukan oleh Fu'ud (2015) mengatakan bahwa biaya lokasi berpengaruh terhadap kesuksesan usaha. Hasil penelitian menunjukkan bahwa biaya lokasi merupakan variabel yang paling besar pengaruhnya terhadap keberhasilan usaha. Hal ini dibuktikan dengan nilai signifikansi 0,000 lebih kecildari 0,05 dengan demikian variabel biaya lokasi berpengaruh terhadap keberhasilan usaha. 


\section{KESIMPULAN DAN SARAN}

\section{Kesimpulan}

Berdasarkan hasil penelitian dan analisis data yang dilakukan, maka dapat disimpulkan sebagai berikut :

1.Pemilihan lokasi berdasarkan faktor lingkungan bisnis berpengaruh terhadap keberhasilan usaha. Artinya semakin baik kondisi lingkungan bisnis disekitar lokasi usaha maka akan semakin mudah keberhasilan usaha dapat tercapai. Sebaliknya semakin buruk kondisi lingkungan bisnis disekitar lokasi usaha maka akan semakin sulit pula tencapainya keberhasilan usaha.

2.Pemilihan lokasi berdasarkan faktor biaya lokasi berpengaruh terhadap keberhasilan usaha. Artinya semakin besar biaya yang di keluarkan untuk memperoleh lokasi usaha maka semakin strategis lokasi tersebut. Semakin strategis lokasi, semakin cepat keberhasilan usaha tercapai. Begitupun sebaliknya semakin kecil biaya yang di keluarkan untuk memperoleh lokasi usaha maka semakin tidak strategis lokasi tersebut. Semakin tidak strategis lokasi maka akansemakin sulit pula tercapainya keberhasilan usaha.

\section{Saran}

Berdasarkan hasil penelitian dan analisis data yang dilakukan, maka disarankan bagi pemilik usaha jasa berskala mikro-kecil khususnya yang berada di sepanjang Jalan Raya UNIB Belakang adalah sebagai berikut:

1.Variabel biaya lokasi memiliki pengaruh paling besar terhadap keberhasilanusaha, oleh karena itupemilik usaha jangan terlalu banyak pertimbangan untuk mendaptkan lokasi tersebut

2.Perlu memperhatikan biaya renovasi yang efisien, efektif dan renovasi bangunan perlu memikirkan kenyamanan bagi konsumen.

\section{DAFTAR PUSTAKA}

Anoraga, Pandji. 2004. Manajemen Bisnis. Jakarta: PT Rineka Cipta.

Chase, R. B. Aquila no, N. J. dan Jacobs, F.R. 2004. Operations Management for Competitive Advantage. China: McGraw-Hill

Fu'ad, N.E. 2015. Pengaruh Pemilihan Lokasi Terhadap Kesuksesan Usaha Berskala Mikro/Kecil Di Komplek Shopping Centre Jepara. Media Ekonomi Dan Manajemen, 30 (1), 62-5

Handoko, H. 2000. Dasar-dasar Manajemen Produksi dan Operasi. Yogyakarta: BPFE.

Haming, Murdifin. DanNurnajamuddin, Mahfud. 2007. Manajemen Produksi Modern:Operasi Manufaktur dan Jasa. Jakarta: PT Bumi Aksara.

Heizer, Jay. dan Render, Barry. 2009. Manajemen Produksi. Jakarta: Salemba Empat. 
Kotler, P. 1997.Manajemen Pemasaran (W. W. Bakuwatun,Trans.). Jakarta: Intermed

Levy, M.danWeitz, B. 2007. Retailing management $6^{\text {th }}$ edition,McGraw Hill International.

Rbayulia. 2013. Analisis Faktor Yang Mempengaruhi Pemilihan Lokasi Terhadap Tingkat Penjualan Pada Usaha Jasa Mikro-Kecil (Studi Kasus: Sekitar Kampus Uin Syarif Hidayatullah Jakarta). Skripsi tidak diterbitkan. Jakarta.

Sekaran, Uma . 2006. Research Methods For Business (Metode Penelitian Bisnis).Jakarta : Salemba Empat.

Sekaran, Uma. 2009. Research Methods For Business (Metode Penelitian Bisnis).Jakarta : Salemba Empat.

Tjiptono, Fandy. 2007. Pemasaran Jasa. Malang: Bayumedia Publishing.

Undang-Undang Republik Indonesia Nomor 20 Tahun 2008 Tentang Usaha Mikro, Kecil, Dan Menengah. 2008. Jakarta.

Wahyudi, N. dan Heriyanto, A.E, 2014. Analisis Faktor-Faktor Pemilihan Lokasi Usaha Terhadap Kesuksesan Usaha Jasa Mikro Di Kecamatan Sungai Kunjang. Jurnal Ekonomi Universitas Samarinda.

Zuliarni, S. dan Hidayat, T.R, 2013. Analisis Faktor Pertimbangan Pebisnis Restoran Kelas Kecil Di Lingkungan Kampus Universitas Riau Dalam Pemilihan Lokasi Usaha. Jurnal Aplikasi Bisnis,3 (2), 107-100. 